\title{
ЯЗЫКОЗНАНИЕ
}

Научная статья

УДК 811

doi: 10.18101/2305-459X-2021-1-3-7

\section{О ФАКТИТИВНОЙ КАУЗАЦИИ В БУРЯТСКОМ ЯЗЫКЕ}

\author{
(C) Дадуева Елена Александровна \\ кандидат филологических наук, докторант, \\ Бурятский государственный университет имени Доржи Банзарова \\ Россия, 670000, г. Улан-Удэ, ул. Смолина, 24а \\ edadueva@yandex.ru
}

Аннотация. Статья посвящена актуальной проблеме разграничения семантикосинтаксических пар фактитивных и пермиссивных значений каузативных конструкций в бурятском языке. Показано, что фактитивная каузация находит явное выражение только в каузативных полипредикативных конструкциях с глаголами волевого воздействия. На морфологическом уровне средствами выражения фактитивной каузации можно назвать суффиксы -га (-го, -гэ), -гаa (-гээ, -гоо, -гөө), -ха (-хэ, -хо), -хаa (-хээ, -хоо), - аa (-ээ, -оо, -өө). В бурятском языке часто фактитивное или пермиссивное значение глагола закрепляется в словарной статье. В статье показано, что для выделения того или иного типа каузации в бурятском языке большое значение имеет контекст. Так, одним из контекстуальных условий актуализации фактитивного значения может быть признак «неприятности».

Ключевые слова: каузативность; каузативный глагол; бурятский язык; фактитивная каузация; пермиссивная каузация.

\section{Для цитирования}

Дадуева $E$. A. О фактитивной каузации в бурятском языке // Вестник Бурятского государственного университета. Язык. Литература. Культура. 2021. Вып. 1. С. 3-7.

К одной из наиболее важных и обсуждаемых проблем в исследованиях каузативности можно отнести разграничение семантико-синтаксических пар фактитивных и пермиссивных значений каузативных конструкций. Необходимо отметить, что в теории каузативности важное место занимают исследования семантики конструкций. При этом значения фактитивной и пермиссивной каузации выделяются как основные семантические характеристики конструкций с каузативными глаголами $[7 ; 1 ; 9 ; 10$; и др.]. Так, каузация, при которой каузатор является основным источником каузируемого действия, считается фактитивной, а каузация, при которой каузатор не представляется основной причиной воздействия, относится к пермиссивной. Например: Та намайе ехээр бү айлгагты 'Вы меня сильно не запугивайте' (ЭКБЯ ${ }^{1}$, Ц. Шагжин. Галта джунгли) (фактитивная кау-

${ }^{1}$ URL: http://webcorpora.net/BuryatCorpus (здесь и далее даны примеры из электронного корпуса бурятского языка - ЭКБЯ) 
зация). При пермиссивной каузации инициатива является прерогативой каузируемого объекта, а каузатор лишь разрешает (не разрешает), допускает или позволяет ему выполнить желаемое действие [7, с. 28]. Например: Бадма һүни болотор зугаалжа намайе унтуулнагүй 'Бадма, разговаривая до самой ночи, не дает мне уснуть :

Семантика фактитивной каузации предполагает, что каузатор не только побуждает объект к выполнению действия, но и может самостоятельно выполнять его, каузируя физическое или эмоциональной состояние. Заметим, что фактитивность иногда понимается как синоним каузативности. Так, например, Т. А. Кильдибекова пишет: «Понятийная категория каузативности (фактитивности, воздействия) ...» [3, с. 13]. Однако большинство исследователей все же выделяют именно два семантических типа каузации - фактитивную и пермиссивную [7; 9; и др.]. При этом большая часть каузативных глаголов в языках отражает фактитивную каузацию, которая считается прототипической, т. е. отражающей значение каузативности в наиболее чистом виде. Пермиссивная каузация признается непрототипической [5; 4 ; 6 ; и др.].

В бурятском языке мы относим к глаголам с фактитивным значением следующие глаголы, которые выступают в качестве матричных предикатов: баалаха (заставить), гуйха (просить), захиха, даалгаха (поручать), аргадаха (уговаривать), зааха (указывать), заабарилаха (дать указание), эрихэ (требовать), эльгээхэ (послать) и др. Такие фактитивные глаголы обозначают волевые воздействия, при которых субъект-каузатор предлагает выполнить действие другому субъекту, однако при этом именно каузатор является основным источником каузируемого действия. В бурятском языке глаголы волевого воздействия с фактитивным значением участвуют в полипредикативных конструкциях с предикатными актантами в форме причастия будущего времени. Например: Тэрэ мүн лэ гэрһээ гарангүй хэбтэхыень баалаба `Н заставляет его лежать дома, не выходя из дома' (ЭКБЯ, Д. Эрдынеев. Хүлэг инсагаална. 1974). Глагол баалаба выражает чисто фактитивное значение каузации 'заставлять, вынуждать'. Именно матричные предикаты выражают в наиболее чистом виде значение каузации.

Если в полипредикативных конструкциях участвуют глаголы со значением определенного сематического типа каузации, то в монопредикативных конструкциях сложнее определить тип каузации. Данное положение связано с тем, что, как указывает В. П. Недялков, каузативная морфема может выражать как пермиссивное, так и фактитивное значение [7, с. 29]. Этот факт находит свое подтверждение и в бурятском языке. Каузативные морфемы могут обозначать оба значения, и в зависимости от ситуации актуализируется тот или иной тип каузации. Так, суффиксы -уул, -лга могут участвовать в образовании глаголов со значением волевого воздействия, т. е. обозначать как принуждение (фактитивность), так и разрешение (пермиссивность). Например: Үбгэн, энэ нүхэрөө абаашажа сайл$\boldsymbol{y} \boldsymbol{y} л-\boldsymbol{a}$, , унт-уул- $\boldsymbol{a}$ 'Старик, уведи своего друга, напои чаем и уложи спать' (ЭКБЯ, Ц. Дон. Брынзын санха. 1935). В этом контексте глаголы сайл-уул-ха `поить чаем', унт-уул-ха 'усыпить, уложить` обозначают действия, зависящие от каузатора, т. е. выражают фактитивную каузацию. Ср.: Хэнииешье энээн руу бү ор-уул-а! 
'Никого сюда не впускай!' ('Никому не разрешай сюда заходить') (ЭКБЯ, В. Гармаев. Гаржаамын таабари. 1992). Глагол ор-уул-ха 'разрешить, позволить зайти` от глагола орохо 'зайти` в этом контексте имеет пермиссивное значение, каузатору необходимо дать или не дать разрешение на действие. Добавим, что в переводных бурятско-русских словарях часто закрепляется за глаголом как фактитивное значение, так и пермиссивное. Например: хэрэлдуулхэ 'ссорить', 'анюулха `велеть закрыть (глаза)', наадуулха 'дать играть '; амаруулха 'давать отдыхать `и т. д. [8]

Между тем В. П. Недялков замечал, что в языках мира встречается употребление каузативных морфем только в фактитивном значении [7, с. 29]. Это предположение оправдывается на материале бурятского языка. По нашим наблюдениям, каузативные аффиксы -га (-го, -гэ), -гаa (-гээ, -гоо, -гөө), -xa (-xэ, -хо), -хаa $(-x э э,-x о o),-a a(-э э,-о o,-ө \theta)$ образуют в основном каузативные глаголы фактитивного значения. Например: хал-аa-xa 'нагревать', хат-aa-xa 'сушить', haл-гaa$x a$ 'разделять', шангад- $x a-x a$ 'усиливать' и т. п. Например: 1) Доржо сайень түргэ түргэн хал-аа-на 'Доржо быстро согрел чай' (ЭКБЯ, Ч. Цыдендамбаев. Түрэл нютагһаa холо. 1958). 2) Дугар тэрээнииень буудажа һал-гаa-ба 'Дугар разнял его, стрельнув' (ЭКБЯ, Б. Шойдоков. Дайсанай ара талада. 1995). Каузатор здесь является основным источником каузативного воздействия. При помощи данных суффиксов образуются в основном глаголы физического и эмоционального воздействия, в семантике которых уже содержится значение непосредственного прямого воздействия, свойственного фактитивной каузации. Например: зоб-оо-хо 'мучить ' - зобо-хо 'мучиться', хал- $a a-x a$ 'нагревать' $-x a$ ла-ха 'нагреваться', эс-ээ-хэ 'утомлять' - эсэ-хэ 'утомляться', бусал-га-ха 'кипятить`- бусал- $x a$ `кипятиться` и т. д.

Также в бурятском языке различие пермиссивности и фактитивности происходит при актуализации значения «приятности/неприятности» действия для каузируемого объекта. Ср.: 1) Тэрэ маниие газаа хонуулба 'Он заставил нас ночевать на улице - фактитивная каузация, «неприятное» действие; 2) Тэрэ hайн сэдьхэлтэй эхэнэр маниие гэртээ хонуулба 'Та добрая женщина разрешила нам переночевать у нее дома` - пермиссивная каузация, «приятное» действие [2].

Ср. также: Отеи позволил (разрешил) детям читать (пермиссивная каузация) и Отеи заставил детей читать (фактитивная каузация). Если в русском языке значение пермиссива или фактитива актуализируется при помощи матричных каузативных глаголов, то в бурятском языке такого контекста будет явно недостаточно: Абань ухибуддээ уншуулба. Адекватный перевод такой конструкции практически невозможен без более широкого контекста. Например: Абань ұхибуудээ гұйжэ байхадань, столдо һуулгаад, уншуулба 'Отец заставил детей читать, усадив за стол, когда они бегали`. В таком контексте становится явным фактитивное значение глагола: отец заставил детей читать, чтобы они не бегали, не шумели, а занялись полезным делом - читали. Вряд ли инициатива в этот момент принадлежала детям, для них каузируемое действие было, скорее всего, «неприятным», отец здесь является каузатором, т. е. непосредственным источником нежелательного воздействия. 
Таким образом, в бурятском языке семантическая корреляция фактитивных и пермиссивных значений находит свое место. Так, фактитивная каузация явно выражается только в каузативных полипредикативных конструкциях с глаголами волевого воздействия. На морфологическом уровне средствами выражения фактитивной каузации можно назвать суффиксы -га (-го, -гэ), -гаa (-2ээ, -гоо, -2өө), $-x a(-x \ni,-x o),-x a a(-x э э,-x о o),-a a(-э э,-о o,-ө \theta)$. В бурятском языке часто фактитивное или пермиссивное значение глагола закрепляется в словарной статье. В ней показано, что для выделения того или иного типа каузации в бурятском языке большое значение имеет контекст. Так, одним из контекстуальных условий актуализации фактитивного значения может быть признак «неприятности».

\section{Литература}

1. Абдиев Т. Конструкции с каузативными глаголами в киргизском языке. Бишкек, Изд-во Кыргызско-турецкого университета «Манас», 2009. 114 с. Текст: непосредственный.

2. Дадуева Е. А. Каузативные глаголы с пермиссивным значением в бурятском и русском языках // Oriental Studies. 2019. № 4(1). С. 99-107. Текст: непосредственный.

3. Кильдибекова Т. А. Глаголы действия в современном русском языке. Саратов: Изд-во Сарат. ун-та, 1985. 160 с. Текст: непосредственный.

4. Ковалева Л. М. Английская грамматика: от предложения к слову. Ч. 1. Пропозиция. Иркутск: Изд-во ИГЛУ, 2006. 169 с. Текст: непосредственный.

5. Лакофф Дж., Джонсон М. Метафоры, которыми мы живем: пер. с англ./ под ред. и с предисл. А. Н. Баранова. Москва: Едиториал УРСС, 2004. 256 с. Текст: непосредственный.

6. Летучий А. Б. Каузатив, декаузатив и лабильность // Аспекты полисинтетизма: очерки по грамматике адыгейского языка / отв. ред. Я. Т. Тестелец. Москва: Изд-во РГГУ, 2009. 715 с. Текст: непосредственный.

7. Типология каузативных конструкций. Морфологический каузатив / отв. ред. А. А. Холодович. Ленинград: Наука, 1969. 311 с. Текст: непосредственный.

8. Черемисов К. М. Бурятско-русский словарь. Москва: Советская Энциклопедия, 1973. 803 с. Текст: непосредственный.

9. Чудинов А. П. Семантическое варьирование русского глагола. Свердловск: Изд-во Свердлов. гос. пед. ин-та. 1984. 72 с. Текст: непосредственный.

10. Shibatani M., Pardeshi P. The causative continuum // The grammar of causation and interpersonal manipulation / Masayoshi Shibatani (ed.). Amsterdam; Philadelphia: John Benjamin, 2002. Р. 96. Текст: непосредственный.

Статья поступила в редакиию 27.01.2021; одобрена после рецензирования 18.02.2021; принята к публикаиии 05.03.2021.

\section{ABOUT ACTUAL CAUSATION IN THE BURYAT LANGUAGE}

Elena A. Dadueva

Cand. Sci. (Phil.), Doctoral Candidate,

Dorzhi Banzarov Buryat State University

24a Smolina St., Ulan-Ude 670013, Russia

edadueva@yandex.ru 
Abstract. The article is devoted to the urgent problem of differentiating semanticsyntactic pairs of factitive and permissive meanings of causative constructions in the Buryat language. It is reaveled that factual causation is explicitly expressed only in causative polypredicative constructions with volitional verbs. The means of expressing factual causation at the morphological level are suffixes -га (-го, -гэ), -гаa (-гээ, -гоо, $-2 \theta \theta),-x a(-x \ni,-x o),-x a a(-x \ni \ni,-x о o),-a a(-э \ni,-o o,-\theta \theta)$. In the Buryat language, the factual or permissive meaning of the verb is often fixed in the dictionary entry. The article shows that the context is of great importance for defining a particular type of causation in the Buryat language. So, one of the contextual conditions for actualizing factitive meaning may be the marker of "unpleasant".

Keywords: causation; causative verb; the Buryat language; factitive causation; permissive causation.

For citation

Dadueva E. A. About Actual Causation in the Buryat Language. Language. Literature. Culture. 2021; 1: 3-7 (In Russ.).

The article was submitted 27.01.2021; approved after reviewing 18.02.2021; accepted for publication 05.03.2021. 